\title{
Relationships between bacterioplankton and phytoplankton biomass, production and turnover rate in Tuamotu atoll lagoons
}

\author{
Jean-Pascal Torréton ${ }^{1, *}$, Jean Pagès ${ }^{2}$, Vincent Talbot ${ }^{2}$ \\ ${ }^{1}$ Institut de Recherche pour le Développement, BP A5, 98848 Nouméa, New Caledonia \\ ${ }^{2}$ Institut de Recherche pour le Développement, Tahiti BP 529 Papeete, French Polynesia
}

\begin{abstract}
As a part of a multi-disciplinary study of the biological production in 12 Tuamotu atoll lagoons, we assessed phytoplankton and bacterioplankton biomass and production. The only consistently significant differences were those existing between lagoons, without any other spatial or seasonal signal. Compared with the surrounding oligotrophic ocean, lagoons displayed an increase in trophic status related to their hydraulic regime (water renewal rate and atoll rim morphology). Bacterioplankton biomass was correlated to phytoplankton biomass (power function, slope $<1$ ), and bacterial carbon exceeded phytoplankton carbon in the most oligotrophic atoll lagoons. Bacterioplankton production and turnover rate were strongly related to phytoplankton production and turnover rate, respectively, by power functions (both slopes $>1$ ). Besides these quantitative differences corresponding to the classical 'inverted trophic pyramid', potential exoproteolytic activity in the lagoons increased, relative to bacterial production, with increasing oligotrophy, hinting at an increased reliance on polymeric dissolved organic matter (DOM). In increasingly oligotrophic lagoons, phytoplankton (although less abundant) may increase its ratio of exuded DOM, but sessile benthic fauna (especially corals) was also found to be more abundant and might enrich the water column with high-nitrogen DOM.
\end{abstract}

KEY WORDS: Bacterioplankton - Phytoplankton - Biomass - Production - Exoproteolytic activity · Atoll lagoons · Oligotrophic ocean

\section{INTRODUCTION}

Oligotrophic oceanic systems have been extensively studied in the last 2 decades. The accumulating body of data now allows the perception of large-scale trends by comparative analysis of different ecosystems. One of the main results is the increasing dominance of heterotrophs, relative to autotrophs, under increasingly oligotrophic conditions (see review by Gasol \& Duarte 2000).

Among the oligotrophic environments, atoll lagoons present interesting variations, since they might be considered to be 'somewhat leaky reaction vessels' (Smith \& Jokiel 1975). They could be seen as continuous culture reactors, flushed from a common oligotrophic

*E-mail: torreton@noumea.ird.nc 'feed tank' (the ocean), but at different 'dilution rates' as a function of their water renewal rate, itself controlled by reef-crest morphometry. We have undertaken a research program (TYPATOLL) to study the reaction of the planktonic food web, especially at the lower rungs of size, to the forcing variable (water renewal rate) imposed by atoll morphology, which can be analyzed on the basis of satellite pictures (Pagès \& Andréfouët 2001). In this report, we present the results of a study of bacterioplankton and phytoplankton biomass and production in 12 atoll lagoons in the Tuamotu Archipelago covering a wide range of chemical and biological conditions, but all of them in the far oligotrophic range. There were 2 main questions: Do we find in these atoll lagoons a dominance of bacterial carbon (BOC) fitting in the now classical inverted trophic pyramid? Does atoll morphology control or modulate the lower levels of the trophic web? 
Another point would deserve some attention: Since nutrient recycling plays an increased role in oligotrophic waters, heterotrophic bacteria could exhibit qualitative enzymatic adaptations. We used exoproteolytic activity as a gauge of the relative importance of polymeric compounds in the BOC requirements. In atoll lagoons, the organic material fueling bacterioplankton may originate from 2 main sources: suspended phytoplankton (excretion, death, sloppy feeding) and sessile benthic organisms, including corals. Although probably less important in the largest atoll lagoons where pelagic processes are predominant over benthic ones, coral mucus has been reported to be an important fraction of reef detrital material (review by Hatcher \& Sammarco 1983). Its high protein content (Meikle et al. 1988, Coffroth 1990) suggests that exoproteolytic hydrolysis of mucus could be a source of nutrients for bacteria (Hoppe et al. 1988).

\section{MATERIALS AND METHODS}

Study sites. This study was performed within the framework of the TYPATOLL program, which tested the hypothesis that atoll geomorphology influences the structure and functioning of the trophic web in its lagoon (Dufour \& Harmelin-Vivien 1997, Adjeroud et al. 2000, Dufour et al. 2001). During this study we sampled 12 atoll lagoons located between $15^{\circ} 45^{\prime}-$ $18^{\circ} 03^{\prime} \mathrm{S}$ and $140^{\circ} 78^{\prime}-145^{\circ} 09^{\prime} \mathrm{W}$ and 6 ocean sites between $15^{\circ} 47^{\prime}-17^{\circ} 30^{\prime} \mathrm{S}$ and $141^{\circ} 57^{\prime}-145^{\circ} 37^{\prime} \mathrm{W}$ in the Tuamotu Archipelago, French Polynesia. In this area, tidal amplitude is low ( $\sim 0.3 \mathrm{~m}$ for spring tides). The region is often windy (annual mean $5.1 \mathrm{~m} \mathrm{~s}^{-1}$; Météo France data for 1995 to 1996). The trade winds, from the eastern quadrant, are the dominant feature (median $6.6 \mathrm{~m} \mathrm{~s}^{-1}, 5 \%$ centile $2.3 \mathrm{~m} \mathrm{~s}^{-1}$, average $7.0 \pm$ $2.6 \mathrm{~m} \mathrm{~s}^{-1}$ ) between May and August.

The atolls of the present study exhibit the general features of the classical coral-reef atoll, with a chain of sand islets strung around an inner lagoon. These islets (motu in the local language) are separated by shallow $(\sim 0.5 \mathrm{~m})$ reef-flat spillways (hoa) or by submerged reef flats. Waves breaking on the reef force water over it, generating a net flow of oceanic water into the lagoon (Tartinville \& Rancher 2000). Passes, corresponding to an interruption in the reef crest, may be present. We shall here consider only the 'permeability' of the atoll rim, defined as the degree of integrity of the rim, which depends on the extent of submerged reef flats, reef-flat spillways and passes relative to dry land (Andréfouët et al. 2001a).

Two extreme situations were encountered with regard to permeability. One extreme is Tekokota, a tilted atoll whose south-eastern rim is drowned, form- ing a very wide but shallow ( 1 m) false pass (permeability $59.5 \%$ ). The Tekokota lagoon hence exhibits a very high flushing rate. The other extreme situation is found in Taiaro, a raised atoll with only 1 hoa that is seldom active (permeability $0.9 \%$ ). The shallow lagoon of Reka-Reka is also nearly land-bound and poorly flushed (permeability $1.7 \%$ ). The proportion of dry land relative to lagoon area is also variable (Table 1), with Reka-Reka and Tepoto (and, to a lesser extent, Taiaro) exhibiting a relatively small lagoon surrounded by a broad rim bearing a dense terrestrial vegetation consisting mostly of ageing coconut tree plantations.

Water temperature was not systematically assessed during our campaigns. A later monitoring of 23 lagoons in the Tuamotu showed a seasonal range of $\sim 3^{\circ} \mathrm{C}$ (from 26 to $29^{\circ} \mathrm{C}$ ), within a latitudinal range of $3^{\circ} \mathrm{C}$ (Pagès \& Prasil in press). Salinity was mostly that of the ocean ( 36.0 PSU), ranging between 35.9 and 36.2 PSU. Taiaro was the only exception, with a nearly constant salinity of $\sim 42$ PSU (Pagès \& Prasil in press).

General water column characteristics in the lagoons have been described (Charpy et al. 1997, Charpy \& Blanchot 1998, Dufour et al. 2001). In relation to the present study, we might underline, first, the importance of dissolved organic nutrients, with $\sim 1 \mathrm{mg}$ dissolved organic carbon (DOC) $\mathrm{l}^{-1}$ (Pagès et al. 1997), a high proportion of dissolved organic nitrogen (DON) (>90\% of total dissolved nitrogen) and a sizeable fraction $(\sim 50 \%)$ of dissolved organic phosphorus (DOP) in the total dissolved phosphorus and, second, an overall trophic gradient, exhibited by practically all descriptors (which are inter-correlated). Among others, planktonic chlorophyll and chromophoric dissolved organic matter (DOM) increase with increasing water residence time in a set of 23 lagoons including those of the present study (Andréfouët et al. 2001b, Pagès \& Andréfouët 2001).

Coral abundance was assessed in the course of the TYPATOLL program. It was found that coral knolls are generally distributed in a rather uniform way throughout the lagoon (i.e. are not limited to the outer reef rim or to the inner shore), and that their abundance increases in well-flushed (and hence more oligotrophic) lagoons (Adjeroud et al. 2000).

Sampling. Most of the atolls were visited 3 times (Table 1): at the end of the dry season (November 1994, TYP1 cruise; November 1995, TYP3 cruise) and at the end of the rainy season (March 1996, TYP4 cruise). The campaigns were done using a French Navy ship (TYP1) and the RV 'Alis' (TYP3 and TYP4).

In each lagoon, we occupied 5 stations, generally between 08:00 and 11:00 h with a central station and 4 other stations approximately N, S, E and W from the central one, all about $500 \mathrm{~m}$ away from the lagoon 


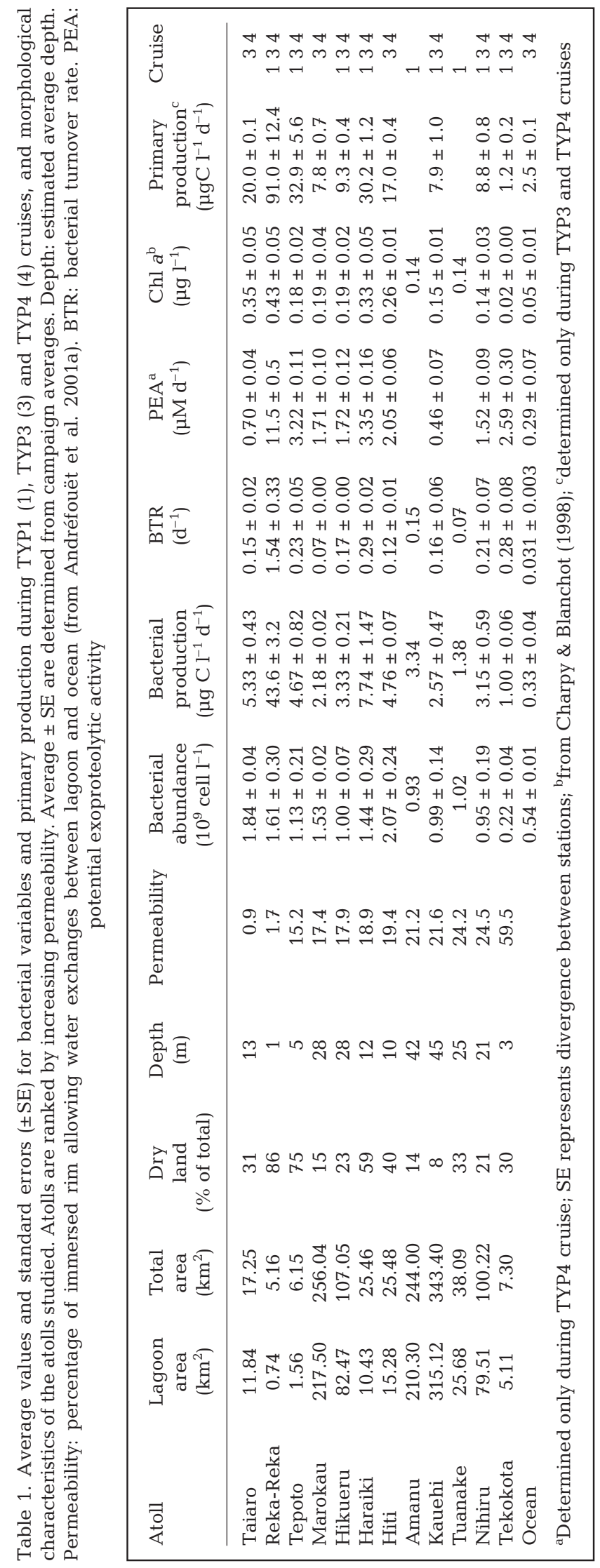

shore. The aim was to test the (probable) spatial homogeneity of the lagoons (see 'Discussion'). Six oceanic stations were occupied during each cruise, targeting locations approximately midway between islands (always more than $5 \mathrm{~km}$ from any atoll).

During the TYP3 and TYP4 campaigns, and for all oceanic stations, only sub-surface samples were taken. Clean (0.1 N HCl) 51 low density polyethylene (LDPE; food grade) jerrycans were directly filled at a depth of $\sim 0.5 \mathrm{~m}$. During TYP1, the central station of each lagoon was sampled at 4 depths equally spaced between surface $(0.5 \mathrm{~m})$ and bottom ( $1 \mathrm{~m}$ above actual bottom) with a 51 Niskin bottle previously soaked in $0.1 \mathrm{~N} \mathrm{HCl}$.

All samples were kept in the dark at in situ temperature until processing on board within $2 \mathrm{~h}$.

Chlorophyll a and primary production. Chlorophyll a (chl a) concentrations were determined by fluorometry (Charpy \& Blanchot 1998). Phytoplankton carbon (PhytoC) was calculated from chl a concentrations using a carbon-to-chlorophyll ratio of 108 (Charpy et al. 1997, see also 'Discussion').

Primary production was determined only during the TYP3 and TYP4 cruises by simulated in situ incubations. Sub-surface samples $(250 \mathrm{ml})$ from the central station only were distributed in 16 cleaned (HCl $1 \mathrm{~N}$ ) polycarbonate Nalgene flasks $(250 \mathrm{ml}$ nominal volume). They received 2.5 or $5 \mu \mathrm{Ci}$ of ${ }^{14} \mathrm{C}$ bicarbonate (Amersham, CFA3). The amount of ${ }^{14} \mathrm{C}$ added was checked in $5 \mathrm{ml}$ aliquots taken just before filtration, amended with $1 \mathrm{ml}$ of ethanolamine. The incubation was performed under artificial light (500 W tungsten halogen bulb) in a vertical incubator cooled by overflowing seawater (pumped from a depth of $\sim 2 \mathrm{~m}$ ). Plastic shades gave 8 different irradiance levels (9 to $1500 \mu \mathrm{E} \mathrm{m}^{-2} \mathrm{~s}^{-1}$, according to a Li-Cor DI-190SA flat, cosine-corrected sensor). After $4 \mathrm{~h}$, samples were filtered onto moistened Whatman GF/F filters under moderate vacuum $(\sim 300 \mathrm{hPa})$, then rinsed with $\sim 25 \mathrm{ml}$ seawater and acidified with $0.1 \mathrm{ml}$ of $1 \mathrm{~N} \mathrm{HCl}$. Filters were kept at $-20^{\circ} \mathrm{C}$ in scintillation vials until counting at the laboratory within $3 \mathrm{wk}$. Samples were radioassayed after adding $10 \mathrm{ml}$ of SigmaFluor (Sigma, S4273) and the quench correction was based on external standards. We did not correct for isotopic discrimination.

Dissolved inorganic carbon (DIC) concentration was determined during the TYP1 cruise. Samples preserved with $\mathrm{HgCl}_{2}$ (final concentration $1 \mathrm{mg} \mathrm{l}^{-1}$ ) were processed by standard alkalinity titration (Sigg et al. 1994) with $0.1 \mathrm{~N} \mathrm{HCl}$ (WTW, pH-3000 pH meter). Most lagoons had DIC concentrations ranging between 2.10 and $2.21 \mathrm{mmol} \mathrm{l}^{-1}$. The 2 prominent outliers were Reka-Reka (1.91 mmol $\mathrm{m}^{-1}$ ) and Taiaro (1.77 mmol $\left.\mathrm{l}^{-1}\right)$, both lagoons being conspicuously confined. 
Incubation irradiance was equated with an in situ irradiance calculated from Secchi disk (SD) readings using $K_{\mathrm{d}} \mathrm{SD}=1.754$ (average determined in Tahiti lagoon, range 1.697 to $1.816, \mathrm{n}=18$ ). We thus defined for each flask pair an 'equivalent depth', which was inserted into the computation of vertically integrated production by the trapezoid rule. Carbon assimilation determined during $4 \mathrm{~h}$ incubations was converted to daily values using the yearly average irradiance of $45 \mathrm{E} \mathrm{m}^{-2} \mathrm{~d}^{-1}$ at Tikehau atoll $\left(148^{\circ} 10^{\prime} \mathrm{W}, 1^{\circ} 00^{\prime} \mathrm{S}\right.$; Charpy 1996). Vertically integrated primary production was normalized to volumetric values by dividing by average lagoon depth.

Phytoplankton turnover rate (PTR) was calculated by dividing volumetric primary production $\left(\mu \mathrm{C} \mathrm{C}^{-1} \mathrm{~d}^{-1}\right)$ by PhytoC ( $\mu \mathrm{g} \mathrm{C}^{-1}$ ) estimated from chlorophyll concentrations (see 'Discussion').

Bacterial abundance, production and potential exoproteolytic activity. Bacterial abundance was estimated by epifluorescence microscopy. Immediately after sampling, $10 \mathrm{ml}$ sub-samples were preserved with borate-buffered formaldehyde ( $2 \%$ final concentration) and were kept cold ( 2 to $4^{\circ} \mathrm{C}$ ) in the dark until filtration on board within $2 \mathrm{~h}$. Nuclepore filters stained with 4',6-diamidino-2-phenylindole (DAPI) (black stained, pore size $0.2 \mu \mathrm{m}$ ) were mounted on slides and were stored frozen $\left(-20^{\circ} \mathrm{C}\right)$ until counting by epifluorescence microscopy within $3 \mathrm{wk}_{\text {; }}$ replicate determinations differ on average by $10 \%$ (Torréton \& Dufour 1996a). Bacterial biomass was computed from these counts assuming a conversion factor of $20 \mathrm{fg} \mathrm{C}$ cell $^{-1}$ (Lee \& Fuhrman 1987; but see 'Discussion').

Bacterial production (BP) was determined from tritiated thymidine $\left({ }^{3} \mathrm{H}-\mathrm{TdR}\right)$ incorporation following standard procedures. Duplicate $10 \mathrm{ml}$ sub-samples and 1 formaldehyde $(2 \%)$ killed control were amended with ${ }^{3} \mathrm{H}$-[methyl]-TdR (20 nM final concentration, $45 \mathrm{Ci}$ $\mathrm{mmol}^{-1}$, Amersham TRK 637) immediately after sampling. Samples were incubated in the dark in an insulated box filled with lagoon surface water $\left(28 \pm 1^{\circ} \mathrm{C}\right)$. After $30 \mathrm{~min}$, the incubation was terminated by adding buffered formaldehyde and unlabeled TdR $(2 \%$ and $1 \mathrm{mM}$ final concentrations, respectively). Killed samples were then stored at 2 to $4^{\circ} \mathrm{C}$ in an insulated box. Onboard, within 90 min, labeled material was collected on Nuclepore membranes $(0.2 \mu \mathrm{m}$ pore size) under gentle vacuum $(<100 \mathrm{hPa})$ and rinsed with $0.2 \mu \mathrm{m}$ filtered lagoon water. The vacuum was disconnected and the filters received $15 \mathrm{ml}$ of ice-cold $5 \%$ trichloroacetic acid (TCA). After 15 min the vacuum was reapplied and the filters were rinsed 4 times with $5 \mathrm{ml}$ of ice-cold $5 \%$ TCA and once with $3 \mathrm{ml}$ of ice-cold ethanol (80\% v/v in water). The filters were stored in scintillation vials at $-20^{\circ} \mathrm{C}$ until processing at the laboratory within $3 \mathrm{wk}$. Labeled DNA was hydrolyzed by heating with $0.5 \mathrm{ml}$
$\mathrm{HCl} 0.5 \mathrm{~N}$ at $100^{\circ} \mathrm{C}$ for $30 \mathrm{~min}$. After cooling, $10 \mathrm{ml}$ of scintillation cocktail was added. Incorporation was determined after quench correction by external standards and BP was computed from TdR incorporation assuming that labeled DNA represented $73.6 \pm 1.7 \%$ of the label in the TCA precipitate (Torréton \& Dufour 1996a) and using a thymidine conversion factor (TCF) of $1.0 \pm 0.4 \times 10^{18}$ cell mol $^{-1} \mathrm{TdR}$ (Torréton \& Dufour 1996b) and $20 \mathrm{fg} \mathrm{C} \mathrm{cell}^{-1}$ (Lee \& Fuhrman 1987).

The turnover rate of bacterial biomass (BTR) was computed from bacterial (carbon) biomass (see above) and $\mathrm{BP}$ rate.

Potential exoproteolytic activity (PEA) was estimated only during the TYP4 cruise, according to Hoppe (1993). We assessed the hydrolysis rate of L-leucine 7 amido-4-methyl coumarin (leu-MCA, Sigma), which competes well with easily degradable natural peptides (Chróst 1991). Duplicate $5 \mathrm{ml}$ sub-samples were incubated with leu-MCA (200 $\mu \mathrm{M}$ final concentration, experimentally verified kinetically saturating concentration) at in situ temperature for $2 \mathrm{~h}$. Hydrolysis was stopped by the addition of sodium dodecylsulfate (SDS) to a final concentration of $1 \%$ (Delmas \& Garet 1995) and samples were stored in the dark at $-20^{\circ} \mathrm{C}$ until analysis. Each duplicate was accompanied by 1 SDS-killed control. The fluorescent product MCA was measured with a Waters 470 scanning fluorescence detector (excitation $385 \mathrm{~nm}$, emission $445 \mathrm{~nm}$ ) previously calibrated with MCA standards. As exoproteolytic activity was measured at saturating concentration of leu-MCA, which was much higher than the in situ concentration of proteins, it must be considered to be a potential activity proportional to the amount of exoenzymes present, but not the real in situ activity.

ANOVA was performed using Statistica software, and model II regressions were performed according to Legendre (2000; see also www.fas.umontreal.ca/biol/ casgrain/fr/labo/model-ii.html).

\section{RESULTS}

\section{Spatial and temporal variation of bacterial variables}

Bacterial biomass, BP and BTR did not show any significant trend with depth. All 3 parameters exhibited coefficients of variation (CV) ranging between 10 and $25 \%$ along depth profiles.

The 3 descriptors did not differ significantly between the 5 stations of the same lagoon (3-way ANOVA; Table 2). Differences between atolls were always significant (Table 2). We conclude that the lagoons were homogeneous and can be described by averaged values. Except for bacterial biomass, no significant difference was found between seasons (Table 2), save 
Table 2. Three-way ANOVA for bacterial biomass, production and turnover rate. Log-transformed data. The analysis was done only on the 7 atolls sampled during the 3 cruises (see 'Materials and methods'). Potential exoproteolytic activity (PEA), determined only during TYP4 cruise, is not included in the analysis. ns: not significant

\begin{tabular}{|llcrc|}
\hline Variable & Effect & df effect & F-ratio & p-value \\
\hline Biomass & Station & 4 & 0.4 & ns \\
& Atoll & 6 & 36.3 & $<0.001$ \\
& Season & 1 & 4.4 & $<0.05$ \\
Production & Station & 4 & 1.6 & ns \\
& Atoll & 6 & 84.1 & $<0.001$ \\
& Season & 1 & 3.4 & ns \\
Turnover & Station & 4 & 0.6 & $\mathrm{~ns}$ \\
rate & Atoll & 6 & 15.2 & $<0.001$ \\
& Season & 1 & 0.0 & $\mathrm{~ns}$ \\
\hline
\end{tabular}

for 1 lagoon (Haraiki) with a suspiciously high bacterial biomass during the TYP4 cruise only.

\section{Lagoon average values of bacterial variables: comparison with oceanic surface waters}

Bacterial abundance was higher in all lagoons except Tekokota $\left(0.13 \times 10^{9}\right.$ to $0.30 \times 10^{9}$ cells $\left.\mathrm{l}^{-1}\right)$ than in oceanic surface waters $\left(0.53 \times 10^{9}\right.$ to $0.56 \times 10^{9}$ cells $\mathrm{l}^{-1}$, Table 1). BP was maximal in Reka-Reka (36 to 49 $\mu \mathrm{g} \mathrm{C} \mathrm{l}^{-1} \mathrm{~d}^{-1}$ ) and minimal (0.9 to $1.2 \mu \mathrm{g} \mathrm{C} \mathrm{l}^{-1} \mathrm{~d}^{-1}$ ) in Tekokota (Fig. 1). All lagoons had significantly higher $\mathrm{BP}$ relative to surface oceanic waters $\left(0.3\right.$ to $0.4 \mu \mathrm{g} \mathrm{Cl}^{-1}$ $\mathrm{d}^{-1}$ ). BTR varied widely between lagoons with maximal values in Reka-Reka (1.0 to $2.3 \mathrm{~d}^{-1}$ ) and minimal values in Marokau $\left(0.07 \mathrm{~d}^{-1}\right)$. BTR in lagoons were systematically greater than oceanic values (0.028 to $\left.0.038 \mathrm{~d}^{-1}\right)$. PEA in atoll lagoons ranged from $0.46 \mu \mathrm{mol} \mathrm{d}^{-1}$

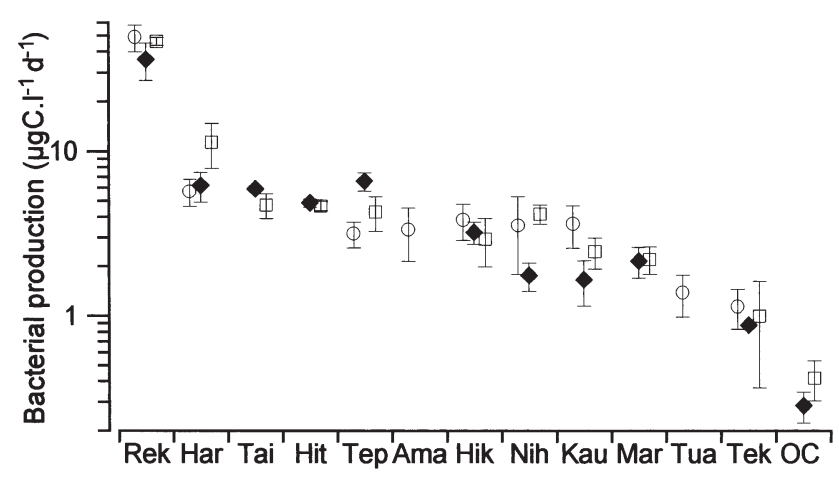

Fig. 1. Average bacterial production rate in each atoll determined during TYP1 (O), TYP3 ( $\bullet$ ) and TYP4 () campaigns. Atolls are designated by their first 3 letters (see Table 1 for full names) and ranked by decreasing production rate. OC: oceanic stations. Error bars are standard errors (SE) among 5 stations
(Kauehi) to $11.5 \mu \mathrm{mol} \mathrm{d} \mathrm{d}^{-1}$ (Reka-Reka) and was systematically higher than oceanic activity (0.29 \pm $0.07 \mu \mathrm{mol} \mathrm{d}{ }^{-1}$ ).

The above differences hint at a probable effect of a hydraulic regime upon bacterial variables. The 'permeability' descriptor indeed was negatively correlated with campaign-averaged bacterial abundance $\left(\mathrm{r}^{2}=\right.$ $0.31, \mathrm{p}<0.01)$, BP $\left(\mathrm{r}^{2}=0.54, \mathrm{p}<0.001\right)$ and bacterial turnover time $\left(r^{2}=0.18, p<0.05\right)$. In the same vein, the ratio of PEA to $\mathrm{BP}$ showed a positive correlation with permeability $\left(r^{2}=0.43, p<0.05\right)$, i.e. potential proteolysis was relatively more active in well-flushed (and more oligotrophic) lagoons.

\section{Primary production}

The lagoon of Tepoto showed improbably high photosynthesis during the TYP3 campaign, both in absolute values and in biomass-specific figures. Although no gross error could be found, we decided not to use these data in further analyses.

Biomass-specific maximum production $\left(P_{\mathrm{M}}^{\mathrm{b}}\right)$ was generally highest under (equivalent) sub-surface irradiance, without any photoinhibition. Maximum rates varied between 3 to $4 \mathrm{mg} \mathrm{C} \mathrm{mg}^{-1} \mathrm{chl} \mathrm{a} \mathrm{h}^{-1}$ (Marokau and Nihiru) and 12 to $19 \mathrm{mg} \mathrm{C} \mathrm{mg}^{-1} \mathrm{chl} \mathrm{a} \mathrm{h}^{-1}$ in RekaReka. On an areal basis, primary production determined at the central station varied between $2.4 \mathrm{mg} \mathrm{C}$ $\mathrm{m}^{-2} \mathrm{~d}^{-1}$ (Tekokota, TYP3) and $486 \mathrm{mg} \mathrm{C} \mathrm{m}^{-2} \mathrm{~d}^{-1}$ (Kauehi, TYP4), stressing that these differences are partly due to depth of the lagoons. This effect of (euphotic or bathymetric) depth is underlined by the relatively low values found both in Reka-Reka ( 90 mg C $\left.\mathrm{m}^{-2} \mathrm{~d}^{-1}\right)$ and in the ocean $\left(\sim 120 \mathrm{mg} \mathrm{C} \mathrm{m}^{-2} \mathrm{~d}^{-1}\right)$. Normalized by average depth (Table 1$)$, primary production ranged from $0.8 \mu \mathrm{gC} \mathrm{l}^{-1} \mathrm{~d}^{-1}$ in Tekokota (TYP3) up to $126 \mu \mathrm{g} \mathrm{C} \mathrm{l}^{-1} \mathrm{~d}^{-1}$ (Reka-Reka TYP3), whereas surface oceanic water values were 2.3 to $2.6 \mu \mathrm{g} \mathrm{C} \mathrm{l}^{-1} \mathrm{~d}^{-1}$.

The PTR (phytoplankton production [PP]:PhytoC) ranged from $0.3 \mathrm{~d}^{-1}$ at Kauehi (TYP3) to $2.0 \mathrm{~d}^{-1}$ at Reka-Reka (TYP3).

Depth-averaged primary production was negatively correlated with permeability $\left(\mathrm{r}^{2}=0.47, \mathrm{p}<0.001\right)$. Chlorophyll concentrations (taken from Charpy et al. 1997) were negatively correlated with permeability $\left(\mathrm{r}^{2}=0.45, \mathrm{p}<0.001\right)$.

\section{DISCUSSION}

\section{Spatial and temporal distribution of variables}

Bacterial variables varied little between stations in each lagoon. Bacterial variables also showed low 
variation with depth (CV 10, 21 and $25 \%$ for bacterial biomass, BP and BTR, respectively) with no consistent structure. Both patterns are in agreement with the vertical and horizontal uniformity of bacterial processes already reported for Tikehau lagoon (Torréton \& Dufour 1996b) and in the Great Astrolabe Reef lagoon (Torréton 1999). This homogeneity is shared by other biological (including chl $a_{\text {; }}$ see Delesalle et al. 2001, for Takapoto) and chemical variables (Charpy et al. 1997, Dufour et al. 2001) and is probably due to rapid mixing by trade winds (see 'Study sites'). During a previous study done in Tikehau lagoon, day-to-day variations of bacterial variables were of the same order of magnitude as differences between different periods of the year (Torréton \& Dufour 1996b). During the same previous study, dayto-day variations of bacterial abundance were shown to be related to wind fluctuations. Differences in wind stress during the days preceding sampling may be responsible for the differences observed between TYPATOLL campaigns. Unfortunately, the absence of regular and detailed wind records in these remote areas prevents us from testing this hypothesis for the TYPATOLL cruises.

\section{Biomass assessment: counts and conversion factors}

We determined bacterial abundance by epifluorescence microscopy. Despite earlier caveats about possible overestimation (Campbell et al. 1994), the contribution of weakly fluorescing prochlorophytes to total bacterial counts appears generally low in tropical oceans (Binder et al. 1996). In this study, misidentification under epifluorescence microscopy may be of minor importance since prochlorophytes enumerated using flow cytometry (Charpy \& Blanchot 1998) represented between 0 and $12 \%$ of DAPI-stained bacteria in these surface waters.

Bacterioplankton carbon was computed from epifluorescence counts using $20 \mathrm{fgC}$ cell $^{-1}$ (Lee \& Fuhrman 1987). This value is still debated since a recent work suggested an almost 2-fold lower cell content in oligotrophic waters (12.4 fg C $\mathrm{cell}^{-1}$, Fukuda et al. 1998). Using this latter value does not influence the pattern of bacterioplankton carbon versus PhytoC but limits the dominance of bacterial biomass to the most oligotrophic atolls (5 of 29 cases using $12.4 \mathrm{fg} \mathrm{C} \mathrm{cell}^{-1}$, instead of 21 of 29 cases -12 lagoons sampled during 1 to 3 cruises - using $20 \mathrm{fg} \mathrm{C}$ cell $\left.{ }^{-1}\right)$.

PhytoC was computed from chl a concentration using a PhytoC to chl a ratio derived from the same atolls. Charpy \& Blanchot (1998) estimated picophytoplankton carbon from flow cytometric forward light scatter and volume-to-carbon conversion factors (Verity et al. 1992). Using their picophytoplankton carbon and chl a values in the TYPATOLL lagoons (Table 4 in Charpy \& Blanchot 1998) gives a median $( \pm \mathrm{SE})$ PhytoC to chl a ratio of $84 \pm 14$. This ratio is an underestimation because it assumes that most of the chl $a$ is contained in picophytoplankton cells. And indeed, in Tuamotu atoll lagoons, a large majority of the chl a (78 $\pm 3 \%$, Charpy et al. 1997) passes through $3 \mu \mathrm{m}$ membranes. If we correct this carbon to chl a ratio by the average percentage of chl $a>3 \mu \mathrm{m}$, then the ratio becomes 108 (assuming a carbon to chl a ratio independent of phytoplankton size). Underestimating or overestimating this ratio by $20 \%$ would require unrealistic carbon to chl a ratios of 10 or 206, respectively, in phytoplankton greater than $3 \mu \mathrm{m}$. The high PhytoC to chl a ratio determined in Tuamotu atoll assemblages compared with the generally cited ratio of 50 (Banse 1977) does not influence the pattern of bacterioplankton carbon versus PhytoC. Moreover, more recent studies suggest that open-ocean oligotrophic communities present a much greater PhytoC to chl a ratio $(>100)$ than previously reported (Hewes et al. 1990, Buck et al. 1996).

\section{Bacterial biomass versus phytoplankton biomass}

Oceanic surface waters were characterized by low bacterial abundance $\left(0.54 \pm 0.01 \times 10^{9} \mathrm{l}^{-1}\right.$; Table 1$)$. With the exception of Tekokota, the range for bacterial abundance in atoll lagoons was $0.9 \times 10^{9}$ to $2.1 \times 10^{9}$ cell $\mathrm{l}^{-1}$, and lagoon averages (Table 1 ) were close to values recorded during previous work in Tikehau and

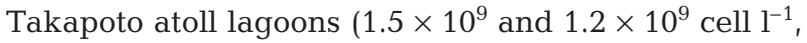
respectively; Torréton \& Dufour 1996a). We found a parallel distribution of phytoplankton abundances. Using the above ratio of 108, PhytoC ranged from $2.1 \mu \mathrm{g} \mathrm{Cl}^{-1}$ (Tekokota TYP3) or $5.4 \mu \mathrm{g} \mathrm{Cl}^{-1}$ in the ocean to $62 \mu \mathrm{g} \mathrm{C}^{-1}$ (Reka-Reka TYP3).

BOC is closely ( $p<0.001$ ) related to PhytoC (Fig. 2, Table 3) by a power function (log-log linear regression type II model). The exponent $(0.79 \pm 0.03)$ is significantly lower than 1 ( $\mathrm{p}<0.001)$. This means that the ratio of $\mathrm{BOC}$ to PhytoC increases in oligotrophic waters.

Numerous studies have shown an analogous correlation between BOC and PhytoC (Gasol \& Duarte 2000, and references therein), with an exponent lower than 1. The dominance of bacterial biomass in the most oligotrophic atoll lagoons is in agreement with large data sets from other oligotrophic environments and follows the concept of the inverted biomass pyramid in oligotrophic waters (reviewed by Gasol et al. 1997 and Biddanda et al. 2001). 


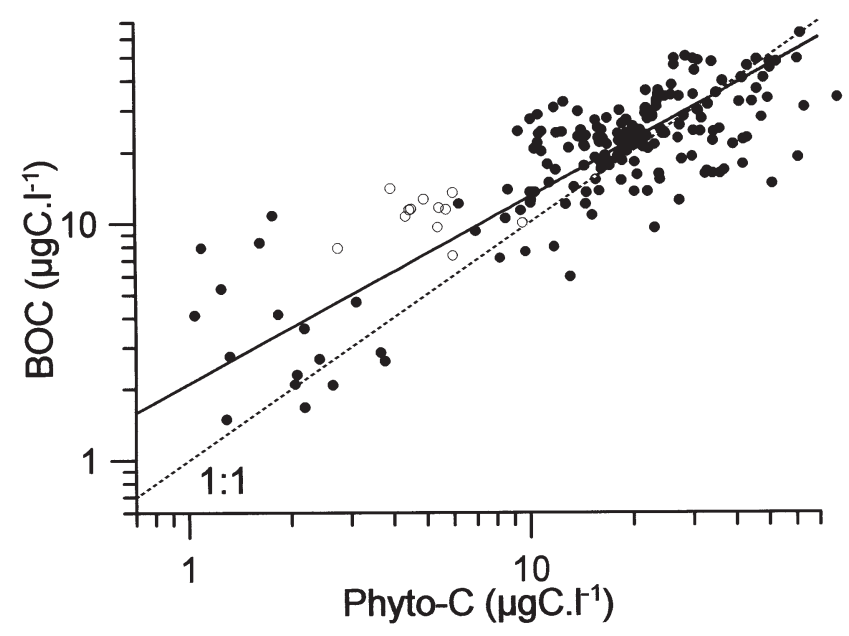

Fig. 2. Scatterplot and correlation model of phytoplankton biomass (PhytoC, using a C:chl a ratio of 108) and bacterial biomass (BOC, using $20 \mathrm{fg} \mathrm{C}^{\mathrm{C}} \mathrm{cll}^{-1}$ ) in Tuamotu atoll lagoons $(\bullet)$ and oceanic surface water $(\circ)$. Solid line represents model II regression fit and dashed line the equivalence of BOC and PhytoC

\section{BP versus primary production}

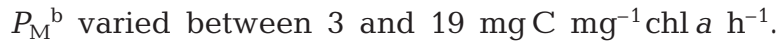
The highest value of $P_{\mathrm{M}}^{\mathrm{b}}$, measured at Reka-Reka, is somewhat suspect. In the particular case of this shallow, mesotrophic lagoon, considering only chl a (and disregarding possible accessory pigments) might well introduce a bias. Apart from this, our $P_{\mathrm{M}}{ }^{\mathrm{b}}$ values are in the range reported in coral lagoons in general, and for Tikehau and Takapoto lagoons over several years of investigation (see review in Delesalle et al. 2001).

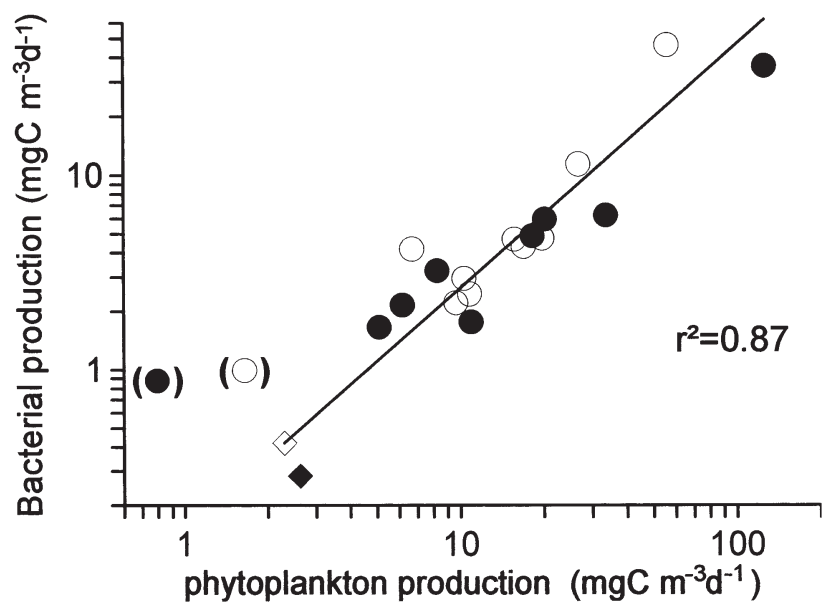

Fig. 3. Scatterplot and correlation model of volumetric phytoplankton (PP) and bacterial production (BP) in Tuamotu atoll lagoons (circles) and surrounding oceanic surface waters (diamonds). Data are from TYP3 (filled symbols) and TYP4 (open symbols) cruises. Tekokota samples between parentheses are not included in the fitted line

$\mathrm{BP}$ in most lagoons was close to those determined in Tikehau and Takapoto atolls (4 to $5 \mu \mathrm{g} \mathrm{C}^{-1} \mathrm{~d}^{-1}$; Torréton \& Dufour 1996a). Concurrent rates in oceanic waters were extremely low $\left(0.33 \pm 0.04 \mu \mathrm{g} \mathrm{C} \mathrm{l}^{-1} \mathrm{~d}^{-1}\right.$; Table 1) and similar to those previously observed in regional oceanic waters (Torréton \& Dufour 1996b). These oceanic production rates are at the lower end of rates reported in the most oligotrophic oceanic waters.

Using production rates expressed per unit of volume, BP is strongly related to primary production by a power function (Fig. 3, Table 3). The exponent (1.25 \pm $0.11)$ is significantly greater than $1(p<0.05)$ and much

Table 3. Summary of the relationships between variables reported in this study. In all cases the relationships are log-log. BOC: bacterial carbon; BP: bacterial production; BTR: bacterial biomass turnover rate; PEA:BP: ratio of potential exoproteolytic activity to bacterioplankton production; leu-MCA: L-leucine 7-amido-4-methyl coumarin; PhytoC: phytoplankton carbon; PP: phytoplankton production; PTR: phytoplankton turnover rate; P Prod: primary production; N: number of points. Intercept, slope and $95 \%$ confidence limits (95\% CL) are calculated according to model II regressions

\begin{tabular}{|c|c|c|c|c|c|c|c|c|c|}
\hline$y$ & $x$ & $y$ [mean (range)] & $x$ [mean (range)] & $\mathrm{N}$ & $\mathrm{R}$ & Intercept & $95 \% \mathrm{CL}$ & Slope & $95 \% \mathrm{CL}$ \\
\hline $\begin{array}{l}\text { BOC } \\
\left(\mu g \mathrm{C}^{-1}\right)\end{array}$ & $\begin{array}{l}\text { PhytoC } \\
\left(\mu \mathrm{C} \mathrm{C}^{-1}\right)\end{array}$ & $21.2(1.0-80)$ & $22.2(1.5-62) \quad 1$ & 157 & 0.81 & 0.32 & $0.24,0.40$ & 0.79 & $0.72,0.86$ \\
\hline $\begin{array}{l}\mathrm{BP} \\
\left(\mu \mathrm{g} \mathrm{Cl^{-1 }} \mathrm{d}^{-1}\right)\end{array}$ & $\begin{array}{l}\text { PP } \\
\left(\mu g \mathrm{Cl}^{-1} \mathrm{~d}^{-1}\right)\end{array}$ & $7.59(0.28-46)$ & $22.7(2.3-126)$ & 19 & 0.94 & -0.83 & $-1.11,-0.60$ & 1.25 & $1.04,1.50$ \\
\hline $\begin{array}{l}\text { BTR } \\
\left(d^{-1}\right)\end{array}$ & $\begin{array}{l}\text { PTR } \\
\left(\mathrm{d}^{-1}\right)\end{array}$ & $0.26(0.07-1.28)$ & $0.65(0.29-2.05)$ & 19 & 0.77 & -0.36 & $-0.47,-0.22$ & 1.58 & $1.15,2.18$ \\
\hline $\begin{array}{l}\text { PEA:BP } \\
\left(\mu \mathrm{mol} \text { leu-MCA } \mu g^{-1} \mathrm{C}\right)\end{array}$ & $\begin{array}{l}\text { Chl a } \\
\left(\mu \mathrm{g} \mathrm{chl} a \mathrm{l}^{-1}\right)\end{array}$ & $0.83(0.15-4.35)$ & $0.25(0.03-0.46)$ & 11 & -0.82 & -1.06 & $-1.47,-0.80$ & -1.07 & $-1.63,-0.70$ \\
\hline $\begin{array}{l}\text { PEA:BP } \\
\left(\mu \mathrm{mol} \text { leu-MCA } \mu g^{-1} \mathrm{C}\right)\end{array}$ & $\begin{array}{l}\text { P Prod } \\
\left(\mu g \mathrm{Cl}^{-1} \mathrm{~d}^{-1}\right)\end{array}$ & $0.83(0.15-4.35)$ & $16.0(1.7-56)$ & 11 & -0.72 & 0.64 & $0.27,1.24$ & -0.91 & $-1.49,-0.55$ \\
\hline $\begin{array}{l}\text { PEA:BP } \\
\left(\mu \mathrm{mol} \text { leu-MCA } \mu g^{-1} \mathrm{C}\right)\end{array}$ & $\begin{array}{l}\text { Corals } \\
\text { (ind. } \mathrm{m}^{-3} \text { ) }\end{array}$ & $0.85(0.15-4.35)$ & $0.23(0.0006-1.17)$ & 9 & 0.75 & 0.22 & $-0.02,0.63$ & 0.46 & $0.26,0.80$ \\
\hline
\end{tabular}


higher than the published values summarized by Gasol \& Duarte (2000). The one exception is Tekokota, which has excessive BP compared with primary production.

\section{BTR versus PTR}

The PTR values (0.3 to $2.0 \mathrm{~d}^{-1}$ ) are in agreement with the paradigmatic elevated turnover rates of autotrophs reported for oligotrophic waters (see Gasol et al. 1997 and references therein). In all of the lagoons, these

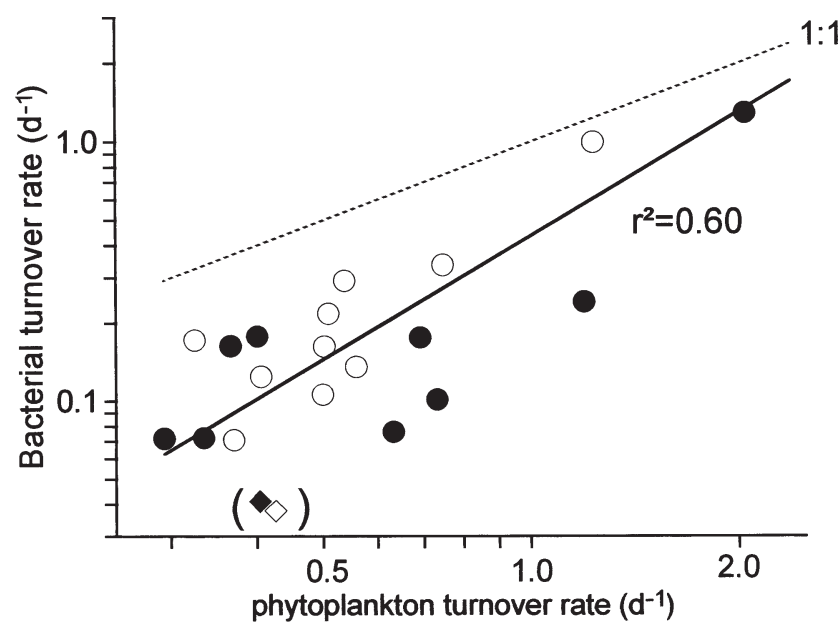

Fig. 4. Bacterioplankton turnover rate (BTR) versus phytoplankton turnover rate (PTR) in the atoll lagoons. Data are from TYP3 (filled symbols) and TYP4 (open symbols) cruises. Data points in parentheses (oceanic samples) are not included in the regression model (solid line). Dashed line represents the equivalence of BTR and PTR

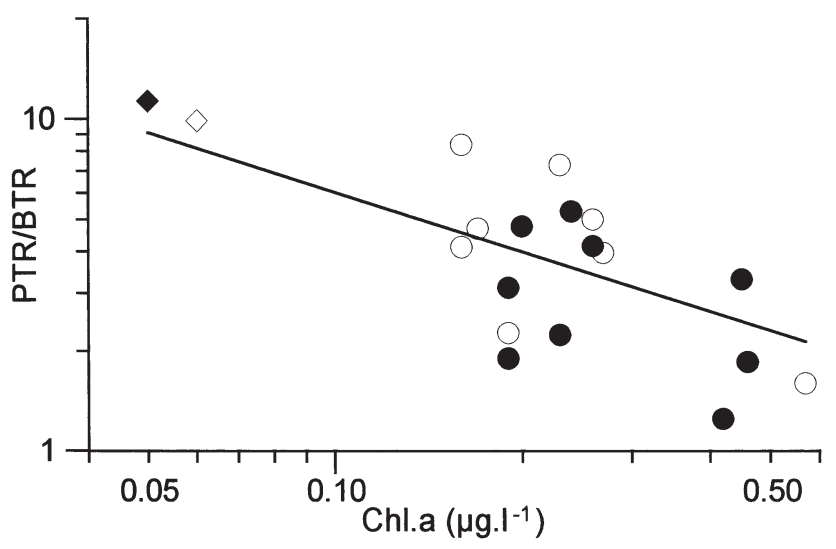

Fig. 5. Ratio of BTR to PTR as a function of chl $a$ in the atoll lagoons (circles) and surrounding oceanic surface waters (diamonds). Data are from TYP3 (filled symbols) and TYP4 (open symbols) cruises. Solid line represents theoretical PTR to BTR ratios calculated from the relationships BOC versus PhytoC and BP versus PP. values are much higher (1.2- to 10.9-fold) than corresponding BTR. In surface oceanic waters, PTR are about 10 times higher than BTR.

BTR are significantly related to PTR (Fig. 4, Table 3), with a power slope $(1.58 \pm 0.24)$ significantly greater than 1 ( $\mathrm{p}<0.03)$. This means that BTR increases, relative to PTR, in eutrophic (or at least mesotrophic) lagoons, so that the ratio of PTR to BTR decreases with increasing chl a (Fig. 5) or decreasing permeability. This latter trend is marred by the data from Tekokota, owing to excessive bacterial activity.

The dominance of PTR relative to BTR in the atoll lagoons studied (19 of 19 cases, i.e. 10 lagoons where PP was determined during TYP3 and TYP4 cruises, excluding Tepoto TYP3) using $1 \times 10^{18}$ cells mol $^{-1}$ is large enough to hold in the most oligotrophic atoll lagoons even if we grossly underestimated TCF by 2fold (15 of 19 cases using the most frequently used TCF value of $2 \times 10^{18}$ cells mol $^{-1} \mathrm{TdR}$, Ducklow \& Carlson 1992). This dominance would of course remain unchanged if we overestimated bacterial carbon content using $20 \mathrm{fg} \mathrm{C} \mathrm{Cell}^{-1}$, since this BOC content is used both in bacterial biomass and in BP computations. On the other hand, overestimation of the PhytoC to chl a ratio would raise PTR and reinforce the dominance of PTR relative to $\mathrm{BTR}$.

\section{Possible trophic links with benthos}

Throughout the above discussion, we have several times found that Tekokota was the most oligotrophic among the lagoons, and even more oligotrophic than the ocean for some parameters such as chl a (0.02 to 0.03 and 0.05 to $0.06 \mu \mathrm{g} \mathrm{chl} \mathrm{a} \mathrm{l}^{-1}$, respectively), bacterial abundance (Table 1) and autotrophic picoplankton (Charpy \& Blanchot 1998). While water renewal rate may explain a sizeable part of the gradient of trophy among lagoons (Dufour et al. 2001), this factor obviously cannot help in the case of Tekokota. The excess of BTR relative to PTR, compared with the trend observed in this study, hints at some trophic factors particularly effective in this lagoon (but which may well exist, in a less obvious form, along the trophic gradient). Grazing of pico- and nanoplankton by benthic coral-reef organisms like corals (e.g. Ferrier-Pagès et al. 1998) may influence both phytoplankton and bacterioplankton concentrations, and Tekokota has the highest coral cover among the atolls studied (Adjeroud et al. 2000).

Another possible trophic link between bacterioplankton and benthic reef organisms is indicated by the inverse correlations of PEA to BP ratio versus chl $a$, and primary production (Fig. 6A,B). Extracellular enzyme production would then be relatively higher in oligotrophic, phytoplankton-poor, coral-rich waters. 


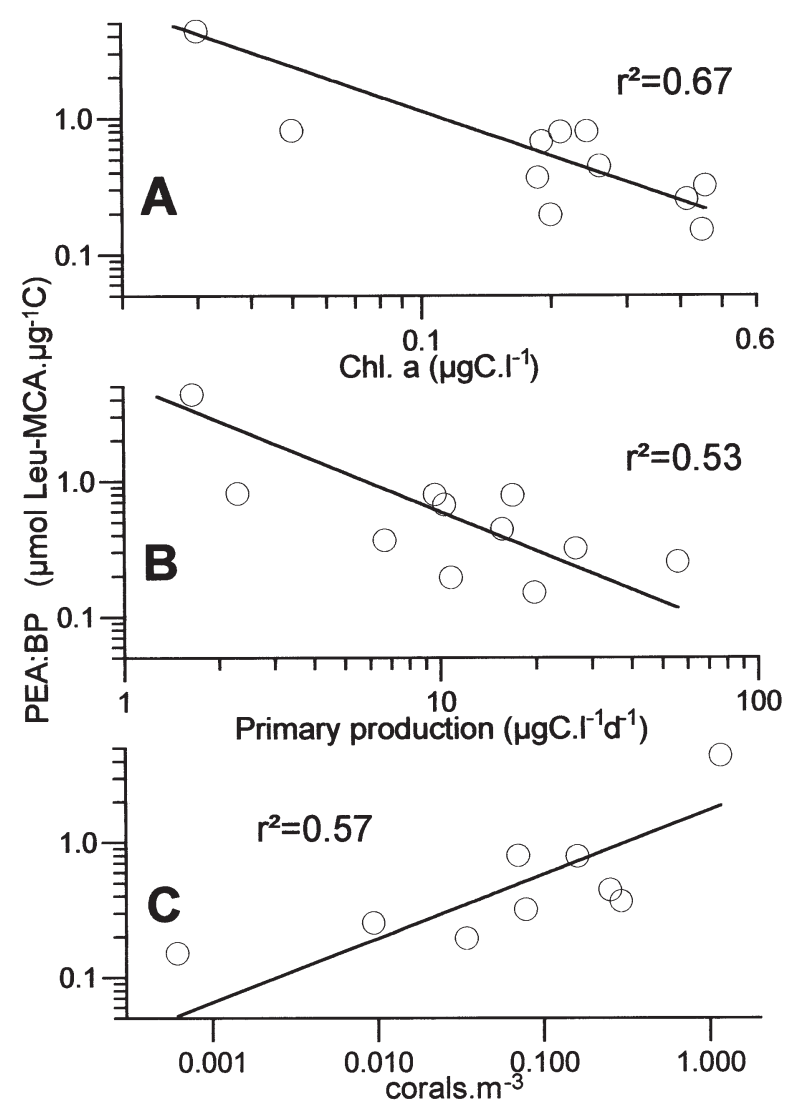

Fig. 6. Ratio of potential exoproteolytic activity to bacterioplankton production (PEA:BP) as a function of (A) chl $a$, (B) PP and (C) coral abundance in the atoll lagoons. Solid lines figure model II regression fits

In coral-reef ecosystems, excretion of mucus by coral has long been recognized as a potentially important source of organic matter for bacterioplankton (Ducklow \& Mitchell 1979). Although, in coral-reef waters, the importance of mucus production to the carbon requirements of bacteria may be questioned (Ducklow 1990), recent studies found experimental (e.g. FerrierPagès et al. 2000) or in situ evidence (e.g. van Duyl \& Gast 2001) of a trophic coupling between corals and bacterioplankton. There is clearly a potential for an alternative source of organic matter for bacterioplankton in coral-reef waters.

In this perspective, we compared the PEA to BP ratio with coral abundance determined by Adjeroud et al. (2000) on 9 lagoons we visited during the TYP4 cruise. Total abundance of corals varies between 0.008 (Taiaro) and 6.2 (Nihiru) colonies $\mathrm{m}^{-2}$ of lagoon area. If corals are likely to influence the water column, coral abundance should be expressed per unit of volume. There is a significant relationship ( $p=0.02$; Table 3 ) between the PEA to BP ratio and volume-specific coral abundance (Fig. 6C). Tekokota, which has an elevated PEA to BP ratio, shows the highest influence of corals on the water column, while Taiaro presents a 30-fold lower PEA to BP ratio for an almost 2000-fold difference in coral potential influence. These trends between PEA to BP ratio and chl a or PP on one hand and coral potential influence on the other could be considered to be an index of a progressive shift between phytoplankton-derived and coral-derived organic matter. Exoenzymatic activity might be due in part to protozoans (Karner et al. 1994), but the ratio of bacterioplankton to heterotrophic nanoflagellates (HNF) abundances in Tekokota (mean $=328, \mathrm{SE}=42$, $\mathrm{n}=13$ ) was comparable with that in other lagoons (373 $\pm 17, \mathrm{n}=120$, Student's $t$-test, Torréton unpubl.). This suggests that the trend is not due to an increasing contribution of HNF to total proteolytic activity.

Interestingly, Hoppe et al. (1988) found a dependency of microbial flora, assessed by maximum cellspecific PEA, on protein-rich mucus excreted in healthy reef sites near Bohol (Philippines). Similarly, Rath et al. (1993) interpreted the maximum cell-specific activity near the barrier reef off Belize as caused by the presence of coral mucus. Our results show a consistent trend between the PEA to BP ratio and coral cover and are in agreement with these observations. Also consistent with this hypothesis is the absence of bacterioplankton growth stimulation by organic and inorganic nutrients in Tekokota in contrast with other atolls (Torréton et al. 2000).

In contrast to Tekokota, Reka-Reka has one of the highest ratios of soft to hard substrate, the shallowest waters, and the highest phytoplankton and bacterioplankton biomasses. Reka-Reka and the closed lagoon of Taiaro show the lowest of PEA to BP ratios along with the lowest coral covers. Moreover, these 2 lagoons are ringed by a particularly broad atoll rim bearing a dense terrestrial vegetation. These lagoons would then easily be heterotrophic systems fuelled by really allochthonous DOM, while coral mucus is 'allochthonous' only in what regards the water column.

\section{Implications of the relationships between bacterioplankton and phytoplankton variables}

In Tuamotu atoll lagoon waters, as in other oligotrophic ecosystems, bacterioplankton are abundant and even dominate living carbon in the most oligotrophic ones, whatever conversion factors might be applied. Hence, bacteria immobilize a considerable portion of nutrients in these ecosystems where nutrients are scarce and likely to constrain both phytoplankton and bacterioplankton growth (Dufour \& Berland 1999, Torréton et al. 2000).

Bacterioplankton biomass production was equivalent to $29 \pm 5 \%$ (median $\pm \mathrm{SE}$ ) of PP. Since carbon 
growth efficiencies are low in comparable environments (Torréton et al. 1997, Torréton 1999), bacterioplankton carbon demand can exceed primary production, at least that determined as ${ }^{14} \mathrm{C}$ incorporation.

There are 2 possible, and not mutually exclusive, ways out of this apparent paradox. The first one is to admit that lagoon water columns are heterotrophic systems fuelled by benthic production, be it from the reef rim or from the bottom. In small and correlatively shallow lagoons such as Hiti, Haraiki or Mataiva, we did find an excess of DOM compared with their computed water renewal rates (Pagès \& Andréfouët 2001). The very frequent trade winds can well provide DOM (and nutrient) transport from the bottom, while overlapping waves scour the reef rim and bring a steady, if small, amount of detrital DOM. The second possibility stems from the physiological release of DOC by phytoplankton. To obviate the lack of actual measurements of DOC production during our study, we may infer from the literature a conservative proportion of about $25 \%$ of particulate photosynthetic production (e.g. Fasham et al. 1999), although much higher proportions (up to $86 \%$ of total organic carbon [TOC] production) have been observed (Carlson et al. 1998). Anyway, these 2 possibilities confirm the need of accounting for DOC production and uptake when trying to balance an energy budget (Fasham et al. 1999).

While bacterioplankton and phytoplankton biomass, BP and BTR vary according to atoll features (opening to the ocean), their respective relationships hold throughout a large range of atoll morphology (permeability and hence water renewal rate) corresponding to a gradient of oligotrophy. These relationships agree well with literature-based ones over a wide range of trophic conditions and extend the data sets available for oligotrophic waters.

Additionally, the PEA to BP ratio is inversely related to the trophic status (i.e. chl $a$, primary production; Fig. 6A,B) of atoll lagoons and correlates with coral abundance normalized to volume. This suggests that bacterioplankton consumption possibly shifts, especially on a qualitative level, from phytoplanktonderived to benthos-derived resources in the most oligotrophic atolls, which harbor (probably not by happenstance) the most abundant coral cover.

Acknowledgements. This work was supported by the Institut de Recherches pour le Développement (IRD, formerly ORSTOM), grants from the Programme National de Recherches sur les Récifs Coralliens (PNRCO) and a grant from the Ministère de la Recherche en Polynésie Française. The first TYPATOLL campaign was done aboard the French Navy patrol ship 'La Railleuse'. We express our gratitude to the crew of the IRD RV 'Alis' for their efficient help during the other TYPATOLL cruises. J. T. Hollibaugh's scientific and linguistic comments were greatly appreciated.

\section{LITERATURE CITED}

Adjeroud M, Andréfouët S, Payri C, Orempüller J (2000) Physical factors of differentiation in macrobenthic communities between atoll lagoons in the central Tuamotu Archipelago (French Polynesia). Mar Ecol Prog Ser 196: $25-38$

Andréfouët $\mathrm{S}$, Claereboudt $\mathrm{M}$, Matsakis $\mathrm{P}$, Pagès J, Dufour P (2001a) Typology of atolls rims in Tuamotu archipelago (French Polynesia) at landscape scale using SPOT-HRV images. Int J Remote Sens 22:987-1004

Andréfouët $S$, Pagès J, Tartinville B (2001b) Water renewal time for classification of atoll lagoons in the Tuamotu Archipelago (French Polynesia). Coral Reefs 20:399-408

Banse K (1977) Determining the carbon-to-chlorophyll ratio of natural phytoplankton. Mar Biol 41:199-212

Biddanda B, Ogdahl M, Cotner J (2001) Dominance of bacterial metabolism in oligotrophic relative to eutrophic waters. Limnol Oceanogr 46:730-739

Binder BJS, Chisholm SW, Olson RJ, Frankel SL, Worden AZ (1996) Dynamics of picophytoplankton, ultraphytoplankton and bacteria in the central equatorial Pacific. DeepSea Res 43:907-931

Buck KR, Chavez FP, Campbell L (1996) Basin-wide distributions of living carbon components and the inverted trophic pyramid of the central gyre of the North Atlantic Ocean, summer 1993. Aquat Microb Ecol 10:283-298

Campbell L, Nolla HA, Vaulot D (1994) The importance of Prochlorococcus to community structure in the central North Pacific Ocean. Limnol Oceanogr 39:954-961

Carlson CA, Ducklow HW, Hansell DA, Smith WO (1998) Organic carbon partitioning during spring phytoplankton blooms in the Ross Sea polynya and the Sargasso Sea. Limnol Oceanogr 43:375-386

Charpy L (1996) Phytoplankton biomass and production in two Tuamotu atoll lagoons (French Polynesia). Mar Ecol Prog Ser 145:133-142

Charpy L, Blanchot J (1998) Photosynthetic picoplankton in French Polynesian atoll lagoons: estimation of taxa contribution to biomass and production by flow cytometry. Mar Ecol Prog Ser 152:67-70

Charpy L, Dufour P, Garcia N (1997) Particulate organic matter in sixteen Tuamotu atoll lagoons (French Polynesia). Mar Ecol Prog Ser 151:55-65

Chróst RJ (ed ) (1991) Microbial enzymes in aquatic environments. Springer-Verlag, New York

Coffroth MA (1990) Mucous sheet formation on poritid corals: an evaluation of coral mucus as a nutrient source on reefs. Mar Biol 105:309-349

Delesalle B, Sakka A, Legendre L, Pagès J, Charpy L, Loret P (2001) The phytoplankton of Takapoto Atoll (Tuamotu Archipelago, French Polynesia): time and space variability of biomass, primary production and composition over 24 years. Aquat Living Resour 14:175-182

Delmas D, Garet MJ (1995) SDS-preservation for deferred measurement of exoproteolytic kinetics in marine samples. J Microbiol Methods 22:243-248

Ducklow HW (1990) The biomass, production and fate of bacteria in coral reefs. In: Dubinsky Z (ed) Coral reefs. Elsevier, Amsterdam, p 265-289

Ducklow HW, Carlson CA (1992) Oceanic bacterial production. Adv Microb Ecol 12:113-181

Ducklow HW, Mitchell R (1979) Bacterial populations and adaptations in the mucus layer on living corals. Limnol Oceanogr 24:715-725

Dufour P, Berland B (1999) Nutrient control of phytoplanktonic biomass in atoll lagoons and Pacific Ocean waters: 
studies with factorial enrichment bioassays. J Exp Biol Ecol 234:147-166

Dufour P, Harmelin-Vivien M (1997). A research program for a typology of atoll lagoons: strategy and first results. Proc 8th Int Coral Reef Symp 1:843-848

Dufour P, Andréfouët S, Charpy L, Garcia N (2001) Atoll morphometry controls lagoon nutrient regime. Limnol Oceanogr 46:456-461

Fasham MJR, Boyd PW, Savidge G (1999) Modeling the relative contributions of autotrophs and heterotrophs to carbon flow at a Lagrangian JGOFS station in the Northeast Atlantic: the importance of DOC. Limnol Oceanogr 44: 80-94

Ferrier-Pagès C, Allemand D, Gattuso JP, Jaubert J (1998) Microheterotrophy in the zooxanthellate coral Stylopora pistillata: effects of light and ciliate density. Limnol Oceanogr 43:1639-1648

Ferrier Pagès C, Leclercq N, Jaubert J, Pelegri SP (2000) Enhancement of pico- and nanoplankton growth by coral exudates. Aquat Microb Ecol 21:203-209

Fukuda R, Ogawa H, Nagata T, Koike I (1998) Direct determination of carbon and nitrogen contents of natural bacterial assemblages in marine environments. Appl Environ Microbiol 64:3352-3358

Gasol JM, Duarte CM (2000) Comparative analyses in aquatic microbial ecology: how far do they go? FEMS Microbiol Ecol 31:99-106

Gasol JM, Del Giorgio PA, Duarte M (1997) Biomass distribution in marine planktonic communities. Limnol Oceanogr 42:1353-1363

Hatcher BG, Sammarco PW (1983) The role of detritus in the metabolism and secondary production of coral reef ecosystems. In: Baker JT, Carter RM, Stark KP (eds) Proceedings of the Great Barrier Reef Conference, James Cook University, Townsville, p 317-325

Hewes CD, Sakshaug E, Reid FMH, Holm-Hansen O (1990) Microbial autotrophic and heterotrophic eukaryotes in Antarctic waters: relationships between biomass and chlorophyll, adenosine triphosphate and particulate organic carbon. Mar Ecol Prog Ser 63:27-35

Hoppe HG (1993) Use of fluorogenic model substrates for Extracellular Enzyme Activity (EEA) measurement of bacteria. In: Kemp PF, Sherr BF, Sherr EB, Cole JJ (eds) Handbook of methods in aquatic microbial ecology. Lewis Publishers, Boca Raton, FL, p 423-431

Hoppe HG, Schramm W, Bacolod P (1988) Spatial and temporal distribution of pelagic microorganisms and their proteolytic activity over a partly destroyed coral reef. Mar Ecol Prog Ser 44:95-102

Karner M, Ferrier-Pagès C, Rassoulzadegan F (1994) Phagotrophic nanoflagellates contribute to occurrence of alpha-glucosidase and aminopeptidase in marine environments. Mar Ecol Prog Ser 114:237-244

Lee S, Fuhrman JA (1987) Relationships between biovolume

Editorial responsibility: Fereidoun Rassoulzadegan,

Villefranche-sur-Mer, France and biomass of naturally derived marine bacterioplankton. Appl Environ Microbiol 53:1298-1303

Legendre P (2000) Régression de modèle II - guide. Département de sciences biologiques, Université de Montréal. Available at: http://www.fas.umontreal.ca/biol/legendre

Meikle P, Richards GN, Yellowlees D (1988) Structural investigations on the mucus from six species of coral. Mar Biol 99:187-193

Pagès J, Andréfouët $S$ (2001) A reconnaissance approach for hydrology of atoll lagoons. Coral Reefs 20:409-414

Pagès J, Prasil V (in press) Effect of water confinement upon pearl-oyster growth rate: food quality vs quantity. Proc 9th Int Coral Reef Symp

Pagès J, Torréton JP, Sempéré R (1997) Dissolved organic carbon in coral-reef lagoons, by high temperature catalytic oxidation and UV spectrometry. CR Acad Sci Paris Ser IIa 324:915-922

Rath J, Schiller C, Herndl GJ (1993) Ectoenzymatic activity and bacterial dynamics along trophic gradient in the Caribbean Sea. Mar Ecol Prog Ser 102:89-96

Sigg L, Stumm W, Behra P (1994) Chimie des milieux aquatiques. Chimie des eaux naturelles, et des interfaces dans l'environnement, 2nd edn. Masson, Paris

Smith SV, Jokiel PL (1975) Water composition and biogeochemical gradients in the Canton atoll lagoon: 1 Lagoon description; design of system analysis; salt and water budget. Mar Sci Commun 1:75-100

Tartinville B, Rancher J (2000) Wave-induced flow over Mururoa atoll reef. J Coast Res 16:776-781

Torréton JP (1999) Biomass, production and heterotrophic activity of bacterioplankton in the Great Astrolabe Reef Lagoon (Fiji). Coral Reefs 18:43-53

Torréton JP, Dufour P (1996a) Bacterioplankton production determined by DNA synthesis, protein synthesis, and frequency of dividing cells in Tuamotu atoll lagoons and surrounding ocean. Microb Ecol 32:185-202

Torréton JP, Dufour P (1996b) Temporal and spatial stability of bacterioplankton biomass and productivity in an atoll lagoon. Aquat Microb Ecol 11:251-261

Torréton JP, Pagès J, Dufour P, Cauwet G (1997) Bacterioplankton carbon growth yield and DOC turnover in some coral reef lagoons. Proc 8th Int Coral Reef Symp 1: 947-952

Torréton JP, Talbot V, Garcia N (2000) Nutrient stimulation of bacterioplankton growth in Tuamotu atoll lagoons. Aquat Microb Ecol 21:125-137

van Duyl FC, Gast GJ (2001) Linkage of small-scale spatial variations in DOC, inorganic nutrients and bacterioplankton growth with different coral reef water types. Aquat Microb Ecol 24:17-26

Verity PG, Robertson CY, Tronzo CR, Andrews MG, Nelson JR, Sieracki ME (1992) Relationships between cell volume and the carbon and nitrogen content of marine photosynthetic nanoplankton. Limnol Oceanogr 37:1434-1446

Submitted: September 11, 2001; Accepted: April 4, 2002

Proofs received from author(s): June 21, 2002 